RESEARCH PAPER RP891

Part of Journal of Research of the National Bureau of Standards, Volume 16, June 1936

\title{
A RAPID METHOD FOR THE DETERMINATION OF SILICA IN PORTLAND CEMENT
}

\author{
By Edwin E. Maczkowske
}

ABSTRACT

If ammonium chloride is mixed with portland cement before the cement is dissolved in hydrochloric acid, and the solution is then digested on the steam bath for 30 minutes, an accurate determination of silica can be made without the customary double evaporation of the solution. The results of the determination of silica in several brands of cement by this modified method are tabulated and compared with the results obtained by the standard method.

\section{CONTENTS}

I. Introduction

II. Recommended procedure for the rapid determination of silica in portland cement.

III. Discussion of the method

\section{INTRODUCTION}

In the course of some work with a silicate of soda (waterglass), it was observed that ammonium chloride, in the presence of hydrochloric acid, facilitated the precipitation of the silicic acid in a thick jellylike mass. This effect of ammonium chloride suggested its possible use to shorten the time required for the determination of silica in materials such as portland cement. Preliminary results indicated that mixing solid ammonium chloride with the cement before it is decomposed with hydrochloric acid makes it possible to dispense entirely with the tedious double evaporation of the solution.

A review of the literature shows that a number of investigators have used ammonium chloride in somewhat similar ways. One of the earliest of these to use ammonium chloride in analyzing silicates decomposable by acids was Barta, ${ }^{1}$ who found that the addition of solid ammonium chloride to the solution containing the silicic acid markedly increased the speed of filtration. Shigeynki Shinkai ${ }^{2} \mathrm{ob}-$ served that when ammonium chloride was added to a silicate hydrosol the latter was transformed into a hydrogel. This observation applied not only to pure silicates, but also to silicates containing $\mathrm{Al}_{2} \mathrm{O}_{3}, \mathrm{Fe}_{2} \mathrm{O}_{3}$, $\mathrm{CaO}$, and $\mathrm{MgO}$.

After the present work was begun, a paper by Zaitzev ${ }^{3}$ appeared which describes the use of ammonium chloride in the analysis of

1 R. Barta, Rev. matériaux construction trav. publics 166, 156 (1923).

2 Shigeynki Shinkai, J. Soc. Chem. Ind., Japan 29, 303-5 (1926).

${ }^{3}$ M. I. Zaitzev, Zavodskaya Lab. 3, 492-4 (1934). 
cement. Zaitzev's method differs from the procedure that was developed in this laboratory, and is described in the next section, since he took a different weight of sample for analysis, and used different quantities of ammonium chloride and acid, and especially since he digested the solution on a steam bath for only 10 minutes.

\section{RECOMMENDED PROCEDURE FOR THE RAPID DETER - MINATION OF SILICA IN PORTLAND CEMENT}

Mix thoroughly $0.500 \mathrm{~g}$ of cement and an approximately equal weight of ammonium chloride crystals in a 50-ml Pyrex beaker, cover the beaker with a watchglass, and add cautiously $5 \mathrm{ml}$ of hydrochloric acid (sp gr 1.18) from a pipette, allowing the acid to run down the lip of the covered beaker.

After the chemical action has subsided, lift the cover slightly and stir the mixture with a glass rod, replace the cover and set the beaker on the steam bath for 30 minutes. During this time of digestion stir the contents occasionally and break up any remaining lumps to facilitate complete solution of the cement.

Fit a 9-cm quantitative filter paper of medium fineness to a funnel, place a small quantity of macerated filter paper, about the size of a large pea, in the bottom of the cone, and wash the filter thus prepared once or twice with hot water. Transfer the jelly-like mass of silicic acid as completely as possible, without dilution, to the filter and allow the hydrochloric acid solution to drain through.

Loosen adhering particles in the beaker by means of a small rubber policeman and wash them on to the filter with hot water; finally wipe the inside of the beaker thoroughly with a small piece of filter paper and place this in the filter. Wash with small portions of hot water, allowing each portion to run through completely, until the volume of the filtrate is about $125 \mathrm{ml}$. Complete the determination by the standard procedure.

\section{DISCUSSION OF THE METHOD}

To compare the results of this modified procedure with the conventional one, seven samples of cement of varying silica content were analyzed by the two methods. Three determinations by each method were made on each sample, and these triplicate determinations were made at different times.

The procedure used for checking the ammonium chloride method was a double dehydration with hydrochloric acid and with a filtration between dehydrations. Platinum dishes were used for evaporation and dehydration. Evaporations were made on the steam bath and the residues were dried for 1 hour at 115 to $120^{\circ} \mathrm{C}$. in an electric oven.

By following the procedure used in standard methods, it is possible to recover, from the $\mathrm{R}_{2} \mathrm{O}_{3}$-group precipitate, silica which may have escaped into the acid filtrate as a soluble silicate. In the present study the silica recovery was not made in all the samples used. However, determinations on a few samples showed that the amount of silica passing into the acid filtrate was small, and of the same order of magnitude in the two methods, varying from 0.2 to $0.9 \mathrm{mg}$.

The results obtained from the determinations of silica on seven samples of portland cement by two analysts are shown in table 1 . 
TABLE 1.-Comparison of results obtained by the rapid and standard methods [ $\mathrm{SiO}_{2}$ IN 0.500-g SAMPLES OF PORTLAND CEMENTS]

\begin{tabular}{|c|c|c|c|c|c|c|c|c|}
\hline \multirow{2}{*}{ Analyst } & \multirow{2}{*}{$\begin{array}{c}\mathrm{Ce}- \\
\text { ment }\end{array}$} & \multirow{2}{*}{$\begin{array}{l}\text { Ex- } \\
\text { peri- } \\
\text { ment }\end{array}$} & \multicolumn{2}{|c|}{ Crude $\mathrm{SiO}_{2}$} & \multicolumn{2}{|c|}{$\begin{array}{l}\text { Residue after } \mathrm{HF} \\
\text { treatment }\end{array}$} & \multicolumn{2}{|c|}{ Refined $\mathrm{SiO}_{2}$} \\
\hline & & & $\begin{array}{l}\text { Rapid } \\
\text { method }\end{array}$ & $\begin{array}{l}\text { Standard } \\
\text { method }\end{array}$ & $\begin{array}{l}\text { Rapid } \\
\text { method }\end{array}$ & $\begin{array}{l}\text { Standard } \\
\text { method }\end{array}$ & $\begin{array}{l}\text { Rapid } \\
\text { method }\end{array}$ & $\begin{array}{l}\text { Standard } \\
\text { method }\end{array}$ \\
\hline 1 & A & $\left\{\begin{array}{l}1 \ldots \ldots \\
2 \ldots \ldots \\
3 \ldots \ldots\end{array}\right.$ & $\begin{array}{c}\mathrm{g} \\
0.1066 \\
.1064 \\
.1068 \\
\end{array}$ & $\begin{array}{c}\mathrm{g} \\
0.1071 \\
.1070 \\
.1067 \\
\end{array}$ & $\begin{array}{r}\mathrm{g} \\
0.0007 \\
.0004 \\
.0008 \\
\end{array}$ & $\begin{array}{l}\mathrm{g} \\
0.0009 \\
.0008 \\
.0005 \\
\end{array}$ & $\begin{array}{c}\mathrm{g} \\
0.1059 \\
.1060 \\
.1060 \\
\end{array}$ & $\begin{array}{l}\mathrm{g} \\
0.1062 \\
.1062 \\
.1062 \\
\end{array}$ \\
\hline A verage value_- & $\ldots$ & & -.......... & $\ldots$ & n............. & - & .1060 & .1062 \\
\hline 1 & B & $\left\{\begin{array}{l}1 \ldots \ldots \\
2 \ldots \ldots \\
3 \ldots \ldots\end{array}\right.$ & $\begin{array}{r}1192 \\
.1188 \\
.1198 \\
\end{array}$ & $\begin{array}{r}.1198 \\
.1200 \\
.1193 \\
\end{array}$ & $\begin{array}{r}.0005 \\
.0004 \\
.0009 \\
\end{array}$ & $\begin{array}{l}.0008 \\
.0009 \\
.0006 \\
\end{array}$ & $\begin{array}{l}.1187 \\
.1184 \\
.1189 \\
\end{array}$ & $\begin{array}{l}.1190 \\
.1191 \\
.1187 \\
\end{array}$ \\
\hline Average value_ & & & $\ldots \ldots \ldots$ & $\ldots \ldots$ & $\ldots \ldots$ & $\ldots \ldots \ldots$ & .1187 & .1189 \\
\hline 1 & C & $\left\{\begin{array}{l}1 \ldots \ldots \\
2 \ldots \ldots \\
3 \ldots \ldots\end{array}\right.$ & $\begin{array}{r}.1105 \\
.1098 \\
.1101 \\
\end{array}$ & $\begin{array}{l}.1100 \\
.1103 \\
.1096 \\
\end{array}$ & $\begin{array}{l}.0013 \\
.0008 \\
.0012 \\
\end{array}$ & $\begin{array}{r}.0009 \\
.0012 \\
.0005 \\
\end{array}$ & $\begin{array}{l}1092 \\
1090 \\
.1089 \\
\end{array}$ & $\begin{array}{l}.1091 \\
.1091 \\
.1091 \\
\end{array}$ \\
\hline A verage value_ & & & -........... & -............. & n.............. & $\begin{array}{ll} \\
-\ldots\end{array}$ & .1090 & .1091 \\
\hline 1 & $\mathrm{D}$ & $\left\{\begin{array}{l}1 \ldots \ldots \\
2 \ldots \ldots \\
3 \ldots \ldots\end{array}\right.$ & $\begin{array}{l}.1008 \\
.1007 \\
.1010 \\
\end{array}$ & $\begin{array}{l}.1015 \\
.1017 \\
.1009 \\
\end{array}$ & $\begin{array}{l}.0004 \\
.0003 \\
.0006 \\
\end{array}$ & $\begin{array}{l}.0010 \\
.0008 \\
.0006 \\
\end{array}$ & $\begin{array}{l}.1004 \\
.1004 \\
.1004 \\
\end{array}$ & $\begin{array}{l}.1005 \\
.1009 \\
.1003 \\
\end{array}$ \\
\hline A verage value & & & ................. & $\ldots$ & (n............ & -.......... & .1004 & .1006 \\
\hline 1 & $\mathrm{E}$ & $\left\{\begin{array}{l}1 \ldots \\
2 \ldots \\
3 \ldots\end{array}\right.$ & $\begin{array}{l}.1004 \\
.1007 \\
.1008 \\
\end{array}$ & $\begin{array}{r}.1002 \\
.1009 \\
.1006 \\
\end{array}$ & $\begin{array}{r}.0006 \\
.0006 \\
.0006 \\
\end{array}$ & $\begin{array}{l}.0007 \\
.0008 \\
.0004 \\
\end{array}$ & $\begin{array}{l}.0998 \\
.1001 \\
.1002 \\
\end{array}$ & $\begin{array}{l}.0995 \\
.1001 \\
.1002 \\
\end{array}$ \\
\hline A verage value_ & 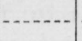 & & - & $\ldots$ & - n......... & -n........ & .1000 & .0999 \\
\hline 1 & F & $\left\{\begin{array}{l}1 \ldots \\
2 \ldots \\
3 \ldots\end{array}\right.$ & $\begin{array}{l}.1076 \\
.1074 \\
.1073 \\
\end{array}$ & $\begin{array}{r}.1072 \\
.1078 \\
.1075 \\
\end{array}$ & $\begin{array}{l}.0006 \\
.0005 \\
.0004 \\
\end{array}$ & $\begin{array}{l}.0008 \\
.0008 \\
.0005 \\
\end{array}$ & $\begin{array}{l}1070 \\
.1069 \\
.1069 \\
\end{array}$ & $\begin{array}{l}.1064 \\
.1070 \\
.1070 \\
\end{array}$ \\
\hline Average value. & $\ldots$ & & …… & - & ב......... & -......... & .1069 & .1068 \\
\hline 2 & $\mathrm{G}$ & $\left\{\begin{array}{l}1 \\
2 \ldots \ldots \\
3 \\
3 \\
4 \\
5 \\
6 \\
6 \ldots \ldots\end{array}\right.$ & $\begin{array}{l}.1029 \\
1033 \\
.1030 \\
.1031 \\
.1031 \\
.1032 \\
\end{array}$ & $\begin{array}{l}.1031 \\
.1037 \\
.1027 \\
.1035 \\
.1029 \\
.1035 \\
\end{array}$ & $\begin{array}{l}.0009 \\
.0008 \\
.0008 \\
.0008 \\
.0009 \\
.0009 \\
\end{array}$ & $\begin{array}{l}.0008 \\
.0008 \\
.0006 \\
.0008 \\
.0007 \\
.0007 \\
\end{array}$ & $\begin{array}{l}.1020 \\
.1025 \\
.1022 \\
.1023 \\
.1022 \\
.1023 \\
\end{array}$ & $\begin{array}{l}.1023 \\
.1029 \\
.1021 \\
.1027 \\
.1022 \\
.1028 \\
\end{array}$ \\
\hline A verage value - & & & & & & --1 & .1023 & .1026 \\
\hline
\end{tabular}

Table 2 shows the results of a further series of experiments, in which four operators used the rapid procedure in comparison with the standard procedure, on a single sample of cement.

TABLI 2.-Determinations on the same sample by different analysts with the rapid method

[ $\mathrm{SiO}_{2}$ IN A 0.500-g SAMPLE OF PORTLAND CEMENT NO. A]

\begin{tabular}{|c|c|c|c|c|c|c|c|c|}
\hline \multirow[b]{2}{*}{ Experiment } & \multicolumn{2}{|c|}{ Analyst 1} & \multicolumn{2}{|c|}{ Analyst 2} & \multicolumn{2}{|c|}{ Analyst 3} & \multicolumn{2}{|c|}{ Analyst 4} \\
\hline & ${ }^{1} \mathrm{SiO}_{2}$ & $\begin{array}{l}\text { Deviation } \\
\text { from } \\
\text { standard } \\
\text { average } \\
\text { value }\end{array}$ & $\mathrm{SiO}_{2}$ & $\begin{array}{l}\text { Deviation } \\
\text { from } \\
\text { standard } \\
\text { average } \\
\text { value }\end{array}$ & $\mathrm{SiO}_{2}$ & $\begin{array}{c}\text { Deviation } \\
\text { from } \\
\text { standard } \\
\text { average } \\
\text { value }\end{array}$ & $\mathrm{SiO}_{2}$ & $\begin{array}{l}\text { Deviation } \\
\text { from } \\
\text { standard } \\
\text { average } \\
\text { value }\end{array}$ \\
\hline & $\begin{array}{l}\mathrm{g} \\
0.1059 \\
.1060 \\
.1060 \\
\end{array}$ & $\begin{array}{c}\mathrm{g} \\
-0.0003 \\
-.0002 \\
-.0002\end{array}$ & $\begin{array}{l}\mathrm{g} \\
0.1058 \\
.1056 \\
.1057\end{array}$ & $\begin{array}{r}\mathrm{g} \\
-0.0004 \\
-.0006 \\
-.0005\end{array}$ & $\begin{array}{c}\mathrm{g} \\
0.1058 \\
.1058 \\
.1059\end{array}$ & $\begin{array}{c}\mathrm{g} \\
-0.0004 \\
-.0004 \\
-.0003\end{array}$ & $\begin{array}{l}\mathrm{g} \\
0.1058 \\
.1060 \\
.1057\end{array}$ & $\begin{array}{r}\mathrm{g} \\
-0.0004 \\
-.0002 \\
-.0005\end{array}$ \\
\hline $\begin{array}{l}\text { A ver a g e } \\
\text { value. }\end{array}$ & .1060 & -.0002 & .1057 & -.0005 & .1058 & -.0004 & .1058 & -.0004 \\
\hline
\end{tabular}

1 The average result obtained by the standard method $=0.1062 \mathrm{~g}$. 
Table 3 shows the effect of the time of digestion on the amount of silica recovered from a sample of portland cement by the rapid method. While 5 to 10 minutes' digestion on the bath, as suggested by Zaitzev, may be satisfactory with most cements, our experience has shown that 30 minutes' digestion is necessary to completely decompose the silicates in some samples.

$\mathrm{T}_{\mathrm{ABLE}}$ 3.-Effect of time of digestion on the amount of silica recovered by the rapid method as compared with the standard method

$\left[\mathrm{SiO}_{2}\right.$ IN A $0.500-\mathrm{g}$ SAMPLE OF CEMENT]

\begin{tabular}{|c|c|c|c|c|c|c|c|}
\hline \multirow[b]{2}{*}{ Sample } & \multicolumn{2}{|c|}{$\begin{array}{l}10 \text { minutes on steam } \\
\text { bath }\end{array}$} & \multicolumn{2}{|c|}{$\begin{array}{c}15 \text { minutes on steam } \\
\text { bath }\end{array}$} & \multicolumn{2}{|c|}{$\begin{array}{c}30 \text { minutes on steam } \\
\text { bath }\end{array}$} & \multirow{2}{*}{$\begin{array}{c}\begin{array}{c}\text { Double de- } \\
\text { hydration }\end{array} \\
\mathrm{SiO}_{2}\end{array}$} \\
\hline & $\mathrm{SiO}_{2}$ & $\begin{array}{l}\text { Deviation } \\
\text { from stand- } \\
\text { ard average } \\
\text { value }\end{array}$ & $\mathrm{SiO}_{2}$ & $\begin{array}{c}\text { Deviation } \\
\text { from stand- } \\
\text { ard average } \\
\text { value }\end{array}$ & $\mathrm{SiO}_{2}$ & $\begin{array}{l}\text { Deviation } \\
\text { from stand- } \\
\text { ard average } \\
\text { value }\end{array}$ & \\
\hline $\begin{array}{l}\mathrm{A} \\
\mathrm{B} \\
\mathrm{C} \\
\mathrm{D}\end{array}$ & $\begin{array}{l}\mathrm{g} \\
0.1050 \\
.1174 \\
.1083 \\
.0996\end{array}$ & $\begin{array}{l}\mathrm{g} \\
-0.0012 \\
-.0015 \\
-.0007 \\
-.0010\end{array}$ & $\begin{array}{l}\mathrm{g} \\
0.1056 \\
.1178 \\
.1085 \\
.1001\end{array}$ & $\begin{array}{l}\mathrm{g} \\
-0.0006 \\
-.0011 \\
-.0005 \\
-.0005\end{array}$ & $\begin{array}{l}\mathrm{g} \\
0.1060 \\
.1187 \\
.1090 \\
.1004\end{array}$ & $\begin{array}{r}\mathrm{g} \\
-0.0002 \\
-.0002 \\
.0000 \\
-.0002\end{array}$ & $\begin{array}{l}\mathrm{g} \\
0.1062 \\
.1189 \\
.1090 \\
.1006\end{array}$ \\
\hline
\end{tabular}

The principal advantage of this modified procedure for the determination of silica in cement is that an analysis can be carried to the stage of igniting the silica in about an hour, instead of 1 day, thus expediting not only the determination of silica, but also the preparation of the solution for the determination of other constituents. There may also be a gain in accuracy.

Although the present study of the effect of ammonium chloride on the determination of silica has been limited to the analysis of portland cement, there appears to be no reason why its use cannot be extended to other siliceous materials which are decomposed by acids in preparation for analysis.

Washington, April 18, 1936. 